\title{
Ambliopia anisometropia
}

\author{
Laya Rares
}

\author{
Bagian Ilmu Kesehatan Mata Fakultas Kedokteran \\ Universitas Sam Ratulangi Manado \\ Email: layarares@yahoo.com
}

\begin{abstract}
Anisometropic amblyopia is blurred vision due to refractive anomaly without any anatomical disorders of the eyes. It is frequently found among children in their growth and development periods. The prognosis depends on the ambylopia severity, management, patient's obedience to the management, and age. We report a case of anisometropic amblyopia in a 8-yearold boy with his main complaint was blurred vision of both eyes. The ophthalmological examination showed the visual acuity of both eyes 6/40, PH 6/9. Several tests that showed normal results were as follows: eyeball movements to all directions; pupil responses to light; Hischberg test; cover test dan cover uncover test at near and far distance fixation; alternate cover test; and worth four dots and Maddox rod tests. Cyclopegical refraction with streak retinoscopy at $50 \mathrm{~cm}$ distance resulted in right eye S-4.00 C-3.00 x180 6/9 and left eye S-1.25 C-3.25 x180 6/7.5; autorefraction of right eye S-4.50 C-3.25 x $7^{0}$ and of left eye S-1.25 C-4.25 x171 ${ }^{\circ}$. Anterior and posterior segments of both eyes were normal. Conclusion: In this case, the diagnosis was confirmed as anisometropic amblyopia and compound myopic astigmatism of the right and left eyes. The prognosis was dubia ad bonam. The patient was treated with maximal correction glasses and observed for the first four weeks, and then would be evaluated continuously untill the vision was normal.
\end{abstract}

Keywords: amblyopia anisometropia, vision, refraction anomaly

Abstrak: Ambliopia anisometropia merupakan gangguan penglihatan akibat kelainan refraksi tanpa disertai adanya kelainan anatomik pada mata yang sering terjadi pada masa perkembangan anak. Prognosis sangat tergantung pada derajat ambliopia, penanganan, kepatuhan pasien terhadap penanganan, dan usia pasien. Kami melaporkan kasus ambliopia anisometropia pada seorang anak berusia 8 tahun, dengan keluhan utama penglihatan kedua mata kabur. Dari pemeriksaan oftalmologik didapatkan visus ODS 6/40, PH 6/9. Beberapa pemeriksaan yang dilakukan memperlihatkan hasil normal, yaitu: pergerakan bola mata ke segala arah; respon pupil terhadap cahaya; Hischberg test; cover test dan cover uncover test pada fiksasi jarak dekat dan jauh; alternate cover test; serta worth four dots test dan Maddox rod test. Pemeriksaan refraksi sikloplegik dengan streak retinoscopy pada jarak $50 \mathrm{~cm}$ didapatkan mata kanan S-4,00 C-3,00 x $180^{\circ}$ 6/9 dan mata kiri S-1,25 C-3,25 x180 6/7,5 dan pemeriksaan autorefraksi mata kanan S4,50 C-3,25 x7 ${ }^{0}$ dan mata kiri S-1,25 C-4,25 x171 ${ }^{0}$. Pemeriksaan segmen anterior dan posterior mata kanan dan kiri dalam batas normal. Simpulan: Diagnosis pada kasus ini ialah ambliopia anisometropia ODS dan astigmatisma miopikus kompositus ODS, dengan prognosis dubia ad bonam. Terapi yang diberikan ialah kacamata koreksi maksimal dan diobservasi selama 4 minggu pertama, dan akan dievaluasi terus sampai ketajaman penglihatan normaL.

Kata kunci: ambliopia anisometropia, ketajaman penglihatan, kelainan refraksi 
Ambliopia ialah penurunan visus meskipun dengan koreksi terbaik ketajaman visual (juga disebut sebagai koreksi ketajaman visual jarak jauh) yang tidak dapat dikaitkan secara langsung dengan efek dari kelainan struktural dari mata atau aksis visual. Keadaan ini biasanya unilateral, jarangjarang bilateral Ambliopia menandakan kegagalan perkembangan saraf yang normal dalam sistem visual dewasa dan disebabkan oleh pengalaman visual normal pada awal kehidupan yang dihasilkan dari salah satu hal berikut: strabismus; kelainan refraksi berupa anisometropia atau kelainan refraktif bilateral yang tinggi (isoametropia); dan deprivasi visual. $^{1,2}$

Ambliopia bertanggung jawab untuk onset kasus penurunan visus unilateral dibandingkan semua penyebab lainnya, dengan prevalensi $2 \%-4 \%$ pada populasi Amerika Utara. Selain itu, kondisi ini ialah penyebab paling umum dari gangguan penglihatan unilateral pada orang dewasa yang lebih muda dari 60 tahun. Prevalensi ambliopia meningkat pada anak-anak dengan riwayat keluarga ambliopia, anak yang lahir prematur, dan orang-orang dengan gangguan perkembangan. ${ }^{1,2}$

Pada ambliopia didapatkan adanya kerusakan penglihatan sentral, sedangkan daerah penglihatan perifer dapat dikatakan masih tetap normal. Studi eksperimental pada binatang serta studi klinis pada bayi dan balita mendukung konsep adanya suatu periode kritis yang peka dalam berkembangnya keadaan ambliopia. Periode kritis ini sesuai dengan perkembangan sistem penglihatan anak yang peka terhadap masukan abnormal yang diakibatkan oleh rangsangan deprivasi, strabismus, atau kelainan refraksi yang signifikan. Sistem penglihatan membutuhkan pengalaman melihat dan terutama interaksi kompetitif antar jalur penglihatan di kedua mata pada visual korteks untuk berkembang hingga dewasa. Bayi sudah dapat melihat sewaktu lahir, tapi mereka harus belajar bagaimana menggunakan mata mereka. Mereka harus belajar bagaimana untuk fokus, dan bagaimana cara menggunakan kedua mata bersamaan. Penglihatan yang baik harus jernih, bayangan terfokus sama pada kedua mata. Bila bayangan kabur pada satu mata, atau bayangan tersebut tidak sama pada kedua mata, maka jaras penglihatan tidak dapat berkembang dengan baik, bahkan dapat memburuk. Bila hal ini terjadi, otak akan "mematikan" mata yang tidak fokus dan orang tersebut akan bergantung pada satu mata untuk melihat. ${ }^{1-6}$

Ambliopia diklasifikasikan berdasarkan penyebab yang mendasari kelainan, yaitu: ambliopia strabismik, ambliopia refraktif, dan ambliopia deprivasi visual. Ambliopia refraktif merupakan bentuk umum lain ambliopia dengan konsistensi defokus pada retina sebgai penyebab pada satu atau kedua mata dan dibagi menjadi 2 tipe, yaitu anisometropik dan isoametropik. ${ }^{1,3}$

Ambliopia anisometropik terjadi ketika adanya perbedaan refraksi antara kedua mata yang menyebabkan lama kelamaan bayangan pada satu retina tidak fokus. Jika bayangan di fovea pada kedua mata berlainan bentuk dan ukuran yang disebabkan karena kelainan refraksi yang tidak sama antara kiri dan kanan, maka terjadi rintangan untuk fusi. Terlebih lagi, fovea mata yang lebih ametropik akan menghalangi pembentukan bayangan (formed vision). ${ }^{1,5}$

Derajat ringan anisometropia hiperopia atau astigmatisma (1-2 D) dapat menyebabkan ambliopia ringan. Anisometropia miopia ringan ( $<-3 \mathrm{D}$ ) biasanya tidak menyebabkan ambliopia, tapi miopia tinggi unilateral (- 6 D) sering menyebabkan ambliopia berat. Begitu juga dengan hiperopia tinggi unilateral (+ 6 D). ${ }^{1,2,4}$

Pengobatan ambliopia melibatkan langkah-langkah sebagai berikut, yaitu: menghilangkan (jika diperlukan) setiap obstruksi sumbu visual seperti katarak, koreksi gangguan refraksi yang signifikan, dan penggunaan paksa mata ambliopia 
dengan membatasi penggunaan mata yang lebih baik. ${ }^{1,2,6}$

\section{LAPORAN KASUS}

Seorang anak perempuan berusia 8 tahun, bangsa Indonesia, suku Minahasa, pekerjaan siswa, alamat Jl Wakeke Manado, agama Kristen Prostestan, datang ke poli Mata BLU RSUP Prof. Dr. R. D. Kandou Manado pada tanggal 8 April 2016 dengan keluhan utama kedua mata kabur sejak \pm 2 tahun. Kedua mata kabur disertai dengan nyeri kepala yang terutama dirasakan saat pulang sekolah. Menurut orang tuanya, pasien menonton televisi dengan jarak yang dekat. Riwayat trauma kepala dan penggunaan kacamata sebelumnya tidak ada. Riwayat lahir normal dengan berat badan normal. Riwayat gangguan refraksi usia muda dalam keluarga ada.

Pemeriksaan fisik umum keadaan umum sakit ringan, kesadaran kompos mentis, tekanan darah 110/60 mmHg, nadi 76x per menit, pernapasan $18 \mathrm{x}$ per menit, serta pemeriksaan toraks dan abdomen dalam batas normal.

Pemeriksaan tajam penglihatan dengan Snellen chart didapatkan hasil pada mata kanan 6/40 PH 6/9, mata kiri 6/40 PH 6/9. Pemeriksaan oftalmologik didapatkan mata kanan dan kiri tampak tenang, pergerakan bola mata baik ke segala arah, dan respon pupil terhadap cahaya baik. Pemeriksaan dengan uji Hischberg, cover test dan cover uncover test pada fiksasi jarak dekat dan jauh, serta alternate cover test didapatkan normal. Pemeriksaan worth 4 dots dan Maddox rod didapatkan hasil normal. Pemeriksaan biomikroskopi dan pemeriksaan funduskopi tidak didapatkan adanya kelainan. Pemeriksaan refraksi sikloplegik dengan streak retinoscopy pada jarak $50 \mathrm{~cm}$ didapatkan mata kanan S-4,00 C-3,00 x180 6/9 dan mata kiri S-1,25 C-3,25 x180 $6 / 7,5$ dan pemeriksaan autorefraksi mata kanan S4,50 C-3,25 x $7^{0}$ dan mata kiri S-1,25 C-4,25 $\mathrm{x} 171^{0}$. Pemeriksaan segmen anterior mata kanan dan kiri dalam batas normal. Pemeriksaan segmen posterior mata kanan kiri didapatkan refleks fundus positif uniform; lain-lainnya dalam batas normal.

Diagnosis ditegakkan sebagao ambliopia anisometropia ODS dan astigmatisma miopikus kompositus ODS. Penanganan yang diberikan ialah kacamata dan diobservasi selama 4 minggu. Prognosis untuk kasus ini ialah dubia ad bonam.

\section{BAHASAN}

Diagnosis ditegakkan berdasarkan anamnesis, pemeriksaan oftalmologik, dan pemeriksaan penunjang. Dari anamnesis didapatkan kedua mata kabur sejak \pm 2 tahun lal, disertai nyeri kepala yang terutama dirasakan saat pulang sekolah. Pasien menonton televisi dengan jarak yang dekat. Riwayat trauma pada kepala dan riwayat penggunaan kacamata sebelumnya tidak ada. Riwayat lahir normal, dengan berat badan normal. Riwayat gangguan refraksi usia muda dalam keluarga ditemukan. Hal-hal ini sesuai dengan acuan pustaka yang menyatakan ambliopia seringkali tidak bergejala klinis dan biasanya ditemukan ketika penurunan tajam penglihatan dideteksi dengan pemeriksaan visus pada masingmasing mata. ${ }^{2}$ Seperti halnya pada pasien ini yang dibawa ke poliklinik mata untuk mendapatkan kacamata dan ternyata didiagnosis sebagai ambliopia. Dengan demikian ambliopia seringkali menjadi alasan keterlambatan dari penanganan

Pada pemeriksaan umum didapatkan pasien tampak sehat, anak cukup kooperatif dengan pemeriksa. Pada pemeriksaan oftalmologik didapatkan VOD 6/40 PH 6/9 dan VOS 6/40 PH 6/9. Pemeriksaan lainnya yang telah disebutkan sebelumnya memperlihatkan hasil normal. Pemeriksaan refraksi sikloplegik dengan streak retinoscopy pada jarak $50 \mathrm{~cm}$ didapatkan mata kanan S-4,00 C-3,00 x $180^{0}$ 6/9 dan mata kiri S-1,25 C-3,25 
$x 180^{\circ} 6 / 7,5$. Hal ini sesuai dengan acuan pustaka yang menyatakan ambliopia anisometropia ialah gangguan refraksi berbeda dari kedua mata yang menyebabkan gambar di satu retina menjadi defokus kronis sehingga tajam penglihatan koreksi terbaik yang menurun. Tingkat anisometropia yang dapat menyebabkan ambliopia ialah sebagai berikut: derajat ringan anisometropia hiperopia atau astigmatisma (1-2D) dapat menyebabkan ambliopia ringan; miopia anisometropia ringan (<-3D) biasanya tidak menyebabkan ambliopia; miopia tinggi unilateral (-6D) sering menyebabkan ambliopia berat. Astigmatisma miopikus kompositus didiagnosis bila kedua bayangan jatuh di depan retina. ${ }^{1,7-10}$

Penanganan pasien ini ialah pemberian resep kacamata sesuai hasil streak retinoscopy, artificial tears eyedrop $4 \mathrm{x} 1 \mathrm{gtt}$ ODS. Hal ini sesuai dengan acuan pustaka dimana salah satu prinsip penanganan ambliopia refraktif ialah memberikan resep kacamata dengan koreksi terbaik atau koreksi kacamata secara tepat. ${ }^{1,6}$

Tabel 1. Tabel follow up pasien ambliopia ${ }^{11}$

\begin{tabular}{|c|c|c|c|c|c|c|}
\hline Tipe pasien & $\begin{array}{c}\text { Frekwensi evaluasi/ } \\
\text { tahun pertama }\end{array}$ & visus & refraksi & $\begin{array}{c}\text { Fiksasi } \\
\text { Binokular }\end{array}$ & $\begin{array}{c}\text { Binokular } \\
\text { status }\end{array}$ & Rencana terapi \\
\hline $\begin{array}{l}\text { Bentuk deprivasi } \\
\text { ambliopia }\end{array}$ & $\begin{array}{l}\text { Setiap 2-4 minggu pada } \\
\text { tahun pertama dan setiap } 6 \\
\text { bulan setelahnya }\end{array}$ & $\begin{array}{l}\text { Tiap } \\
\text { kunjungan }\end{array}$ & $\begin{array}{l}\text { Tiap } \\
\text { kunjungan }\end{array}$ & $\begin{array}{l}\text { Bila } \\
\text { dibutuhkan }\end{array}$ & $\begin{array}{l}\text { Tiap } \\
\text { kunjungan }\end{array}$ & $\begin{array}{l}\text { Konsultasi bedah, koreksi } \\
\text { optik (setelah } 1 \text { minggu post } \\
\text { op), oklusi (part time, } 2 \text { jam } \\
\text { hari), stimulasi visual }\end{array}$ \\
\hline \multirow[t]{2}{*}{$\begin{array}{l}\text { Ambliopia } \\
\text { isoametropia }\end{array}$} & $\begin{array}{l}\text { 1.Re-evaluasi 4-6 minggu, } \\
\text { monitor tiap 4-6 bulan }\end{array}$ & \multirow[t]{2}{*}{$\begin{array}{l}\text { Tiap } \\
\text { kunjungan }\end{array}$} & \multirow[t]{2}{*}{$\begin{array}{l}\text { Bila } \\
\text { dibutuhkan }\end{array}$} & \multirow[t]{2}{*}{$\begin{array}{l}\text { Bila } \\
\text { dibutuhkan }\end{array}$} & \multirow[t]{2}{*}{$\begin{array}{l}\text { Tiap } \\
\text { kunjungan }\end{array}$} & 1.Koreksi kaca mata \\
\hline & $\begin{array}{l}\text { 2.Re-evaluasi } 4-6 \text { bulan, } \\
\text { monitor tiap } 2-6 \text { bulan } \\
\text { setelah terapi visual }\end{array}$ & & & & & $\begin{array}{l}\text { 2.Koreksi kaca mata terapi } \\
\text { visus (10 -15x kunjungan) }\end{array}$ \\
\hline \multirow[t]{3}{*}{$\begin{array}{l}\text { Ambliopia } \\
\text { Anisometropia }\end{array}$} & $\begin{array}{l}\text { 1.Re-evaluasi } 4-6 \text { minggu, } \\
\text { monitor tiap 2-6 bulan }\end{array}$ & \multirow[t]{3}{*}{$\begin{array}{l}\text { Tiap } \\
\text { kunjungan }\end{array}$} & \multirow[t]{3}{*}{$\begin{array}{l}\text { Bila } \\
\text { dibutuhkan }\end{array}$} & \multirow[t]{3}{*}{$\begin{array}{l}\text { Bila } \\
\text { dibutuhkan }\end{array}$} & \multirow[t]{3}{*}{$\begin{array}{l}\text { Tiap } \\
\text { kunjungan }\end{array}$} & 1.Koreksi kaca mata \\
\hline & $\begin{array}{l}\text { 2.Re-evaluasi } 4-6 \text { minggu, } \\
\text { monitor tiap 2-4 minggu }\end{array}$ & & & & & $\begin{array}{l}\text { 2.Koreksi kaca mata, oklusi } \\
\text { part time, } 2-5 \text { jam/hari }\end{array}$ \\
\hline & $\begin{array}{l}\text { 3.Re-evaluasi 4-6 bulan, } \\
\text { monitor tiap 2-6 bulan } \\
\text { setelah terapi visual }\end{array}$ & & & & & $\begin{array}{l}\text { 3.Koreksi kaca mata, oklusi } \\
\text { part time, 2-5 jam/hari, } \\
\text { terapi vision (15-25 } \\
\text { kunjungan), reevaluasi dan } \\
\text { penanganan residual } \\
\text { anomali binokuler ketika } \\
\text { visus 20/40-20/60 }\end{array}$ \\
\hline \multirow[t]{2}{*}{$\begin{array}{l}\text { Ambliopia } \\
\text { strabismus } \\
\text { (fiksasi sentral) }\end{array}$} & $\begin{array}{l}\text { 1.Re-evaluasi } 4-6 \text { minggu, } \\
\text { monitor tiap 2-4 minggu }\end{array}$ & \multirow[t]{2}{*}{$\begin{array}{l}\text { Tiap } \\
\text { kunjungan }\end{array}$} & \multirow[t]{2}{*}{$\begin{array}{l}\text { Bila } \\
\text { dibutuhkan }\end{array}$} & \multirow[t]{2}{*}{$\begin{array}{l}\text { Bila } \\
\text { dibutuhkan }\end{array}$} & \multirow[t]{2}{*}{$\begin{array}{l}\text { Tiap } \\
\text { kunjungan }\end{array}$} & $\begin{array}{l}\text { 1.Koreksi kaca mata, } \\
\text { oklusi(full time bila konstant, } \\
\text { part time bila intermittent) }\end{array}$ \\
\hline & $\begin{array}{l}\text { 2.Re-evaluasi } 4-6 \text { bulan, } \\
\text { monitor tiap 2- } 6 \text { bulan } \\
\text { setelah terapi visual }\end{array}$ & & & & & $\begin{array}{l}\text { 2.Koreksi kaca mata, } \\
\text { oklusi(full time bila konstant, } \\
\text { part time bila intermittent), } \\
\text { terapi vision (15-25 } \\
\text { kunjungan), reevaluasi dan } \\
\text { penanganan residual } \\
\text { anomali binokuler ketika } \\
\text { visus 20/40-20/60 }\end{array}$ \\
\hline \multirow[t]{2}{*}{$\begin{array}{l}\text { Ambliopia } \\
\text { strabismus } \\
\text { (fiksasi eksentrik) }\end{array}$} & $\begin{array}{l}\text { 1.Re-evaluasi 4-6 minggu, } \\
\text { monitor tiap 2-4 minggu }\end{array}$ & \multirow[t]{2}{*}{$\begin{array}{l}\text { Tiap } \\
\text { kunjungan }\end{array}$} & \multirow[t]{2}{*}{$\begin{array}{l}\text { Bila } \\
\text { dibutuhkan }\end{array}$} & \multirow[t]{2}{*}{$\begin{array}{l}\text { Tiap } \\
\text { kunjungan }\end{array}$} & \multirow[t]{2}{*}{$\begin{array}{l}\text { Tiap } \\
\text { kunjungan }\end{array}$} & $\begin{array}{l}\text { 1.Koreksi kaca mata, oklusi } \\
\text { (full time bila konstant, part } \\
\text { time bila intermittent) }\end{array}$ \\
\hline & $\begin{array}{l}\text { 2.Re-evaluasi 4-6 bulan, } \\
\text { monitor tiap } 2-6 \text { bulan } \\
\text { setelah terapi visual }\end{array}$ & & & & & $\begin{array}{l}\text { 2.Koreksi kaca mata, oklusi } \\
\text { (full time bila konstant, part } \\
\text { time bila intermittent), terapi } \\
\text { vision (15-25 kunjungan), } \\
\text { reevaluasi dan penanganan } \\
\text { residual anomali binokuler } \\
\text { ketika visus } 20 / 40-20 / 60\end{array}$ \\
\hline
\end{tabular}


Anjuran pada pasien ini ialah melakukan follow up rutin pemeriksaan mata tiap bulan untuk mengetahui perjalanan penyakit apakah terjadi perbaikan status ambliopia dan mendeteksi dini jika ditemukan perubahan ukuran koreksi kacamata.

Idealnya, terapi ambliopia diteruskan hingga terjadi fiksasi alternat atau tajam penglihatan dengan Snellen linear 20/20 (6/6) pada masing-masing mata. Hasil ini tidak selalu dapat dicapai. Sepanjang terapi terus menunjukkan kemajuan, maka penatalaksanaan harus tetap diteruskan.,11-13 Follow up pasien dengan ambliopia tergantung dari jenis ambliopia. Tabel 1 menunjukkan evaluasi ambliopia sesuai tipe. $^{11}$

Prognosis pasien ini ialah dubia ad bonam dengan penanganan yang tepat. Sesuai acuan pustaka, bila penatalaksanaan dimulai sebelum usia 5 tahun, visus normal dapat tercapai. Hal ini akan semakin berkurang seiring dengan pertambahan usia dan hanya kesembuhan parsial yang dapat dicapai bila usia lebih dari 10 tahun. ${ }^{14}$ Waktu yang diperlukan untuk lamanya terapi tergantung pada beberapa hal, yaitu: derajat ambliopia, pilihan terapeutik yang digunakan, kepatuhan pasien terhadap terapi yang dipilih, dan usia pasien. ${ }^{1}$

\section{SIMPULAN}

Ambliopia anisometropia merupakan gangguan penglihatan akibat kelainan refraksi tanpa disertai adanya kelainan anatomik pada mata. Sering terjadi pada masa perkembangan anak. Prognosis sangat tergantung pada derajat ambliopia, penanganan, kepatuhan pasien terhadap penanganan, dan usia pasien.

\section{DAFTAR PUSTAKA}

1. Paysse EA. Pediatric Ophthalmology and Strabismus. American Academy of Ophthalmology. Basic and Clinical
Sciense Course section 10. 2014-2015. Chapter 4, Amblyopia. The Eye M.D. Association; p. 33-40.

2. Kansky JJ, Bowling B. Clinical Ophthalmology A Systematic Approach (7th ed). Section 18, Strabismus. Chapter 2, Amblyopia. Edinburgh: Elsevier, 2011.

3. Gary RD. Amblyopia. Yanoff \& Duker Opthalmology (3rd ed) Chapter 11.12. London: Mosby Elsevier, 2009

4. Rordan-Eva P, Whitcher J, Vaughan D, Asbury T. Vaughan \& Asbury. General Opthalmolgy (16th ed). New York: Lange Medical Bools/McGraw Hill, 2007.

5. Albert D. Amblyopia. Albert \& Jacobiec's Principles and Practice of Ophthalmology E-Book Chapter 300. Saunders Elsevier. 2008

6. Gerstenblith AT, Rabinowitz MP. The Wills Eye Manual: office and emergency room diagnosis and treatment of eye disease (6th ed). Philadelphia: Lippincot Williams and Wilkins, 2012; p. 189-90.

7. Gotz-Wieckowska A, Siwiec-Proscinska J, Dmitriew A, Sas M, Jurkiewicz A, Dernoga E. Amblyopia detection and treatment across Poland-Results of a questionnaire. Arch Med. 2015;8(1): 1-7.

8. Baroncelli L, Maffei L, Sale A. New perspectives in amblyopia therapy on adults: a critical role for the excitatory/inhibitory balance. Front Cell Neurosci. 2011; 5(25):1-6.

9. Yorgun MA, Yülek F, Ugurlu N, Cagil N. Effects of different types of refractive errors on bilateral amblyopia. JCEI. 2012;3(4):467-71.

10. Coleman AL, Collins N, Mizuiri D, Ravetto J, Lum FC. Amblyopia Prefered Practice Pattern. American Academy of Ophthalmology, 2012.

11. American Optometric Association. Optometric Clinical Practice Guideline 4: Care of the patient with amblyopia. St Louis, reviewed 2004.

12. Hoyt C. What is next in amblyopia treatment? AAO Journal. 2015;122(5): 871-3. 
13. Kaphle D, Paudel P, Shrestha JB. Treatment of anisometropic amblyopia in children with refractive correction. JIOM. 2009;31(2):14-8.

14. Bary SR. Successful improvement of eyesight with therapy for patients with lazy eye proven possible at later ages by many new scientific studies. Optometric network. 2009. Available from: www.lazyeye.org. 